\title{
Emlőtumor intracranialis metasztázisainak eredményes szisztémás palliatív kemoterápiája
}

\author{
Sipőcz István dr. ${ }^{1}$ - Pintér Tamás dr. ${ }^{1}$ \\ Skaliczky Zoltán dr. ${ }^{2}$ - Kullmann Tamás dr. ${ }^{1}$ \\ Petz Aladár Megyei Oktató Kórház, ${ }^{1}$ Onkoradiológiai Osztály, ${ }^{2}$ Idegsebészeti Osztály, Győr
}

\begin{abstract}
A szerzők két esetet mutatnak be. A 69 éves nőbetegnél helyileg elórehaladott és pulmonalis, illetve multiplex cerebralis metasztázisokat adó triple negatív ductalis emlódaganatot diagnosztizáltak. A tünetmentes cerebralis metasztázisok komplett radiológiai remisszióját észlelték szisztémás carboplatin-docetaxel $\left(75 \mathrm{mg} / \mathrm{m}^{2}\right)$ kemoterápia mellett. A beteg később palliatív koponyabesugárzást és 2. vonalú kemoterápiát kapott. A diagnózistól számítva másfél évet élt, részlegesen megő́rzött önállósággal. Az 57 éves nóbetegnél meningitis carcinomatosát, nyirokcsomó- és multiplex ossealis metasztázist adó hormonérzékeny lobularis emlődaganatot mutattak ki. A nyirokcsomó-metasztázis megjelenése előtt intrathecalis methotrexat kemoterápiát alkalmaztak, amely mellett neurológiai tünetei megszúntek. A zsigeri metasztázis kifejlódésekor szisztémás ifosfamid $\left(1000 \mathrm{mg} / \mathrm{m}^{2}, 1-3\right.$. nap $)$ - etoposid $\left(100 \mathrm{mg} / \mathrm{m}^{2}, 1-3\right.$. nap $)$ kemoterápiát kapott, amely mellett a nyirokcsomóáttét komplett klinikai remisszióját és a neurológiai tünetmentesség stabilitását észlelték. A meningitis carcinomatosa diagnózisától számítva több mint egy évet élt, önálló életvitellel. Mindkét eset a szisztémás kemoterápia lehetséges hatásosságát mutatja intracranialis metasztázisokat adó emlődaganatok kezelésében. Orv. Hetil., 2016, 157(45), 1809-1813.
\end{abstract}

Kulcsszavak: emlődaganat, cerebralis metasztázis, meningitis carcinomatosa, szisztémás kemoterápia, intrathecalis kemoterápia

\section{Effective systemic palliative chemotherapy for intracranial metastases of breast cancer}

The authors present the history of two patients. The first patient, a 69 -year-old woman was diagnosed with locally invasive triple negative breast cancer with pulmonary and cerebral metastases. Complete radiological remission of the clinically asymptomatic cerebral metastases was detected under systemic chemotherapy with carboplatin-docetaxel $\left(75 \mathrm{mg} / \mathrm{m}^{2}\right)$. Later, the patient received whole brain radiotherapy and a second line of chemotherapy. The overall survival was 20 months from the diagnosis of cerebral metastases with conservation of partial autonomy. The second patient, a 57-year-old woman was diagnosed as having hormone sensitive lobular breast cancer with leptomeningeal, lymphonodular and multiple osseal metastases. Before the appearance of the lymphonodular metastasis the patient received intrathecal methotrexate chemotherapy for the leptomeningeal carcinomatosis. Her neurological symptoms completely disappeared. At the onset of the lymphonodular metastasis systemic chemotherapy with ifosfamide (1000 $\left.\mathrm{mg} / \mathrm{m}^{2}, \mathrm{Dl}-3\right)$ - etoposide $\left(100 \mathrm{mg} / \mathrm{m}^{2}, \mathrm{Dl}-3\right)$ was started allowing complete clinical remission of the lymphadenomegaly and stability of the asymptomatic neurological status. The overall survival was 13 months from the diagnosis of leptomeningeal carcinomatosis with conservation of autonomy. The two cases support potential efficacy of systemic chemotherapy for intracranial metastases of breast cancer.

Keywords: breast cancer, cerebral metastasis, leptomeningeal carcinomatosis, systemic chemotherapy, intrathecal chemotherapy

Sipőcz, I., Pintér, T., Skaliczky, Z., Kullmann, T. [Effective systemic palliative chemotherapy for intracranial metastases of breast cancer. Case report]. Orv. Hetil., 2016, 157(45), 1809-1813.

(Beérkezett: 2016. július 9.; elfogadva: 2016. augusztus 3.) 
Intracranialis metasztázisok leggyakrabban tüdő-, emlő-, vese- és festékes anyajegydaganatok következményeként alakulnak ki. Az intracranialis metasztázisok prognózisa az azonos primer tumor által adott zsigeri metasztázisok prognózisához viszonyítva rosszabb [1]. A prognózis a primer tumor típusától, a szisztémás betegség kontrollálhatóságától, az általános állapottól, az agyi áttétek számától és a metasztázisok megjelenéséig eltelt idő hosszától függ. A 2000-es évek elejéig az agyi áttétes emlődaganatos betegek egyéves túlélési esélye $20 \%$ volt [1]. Egy újabb, kis esetszámú vizsgálat szerint az agyi áttétek diagnózisától számítva az átlagos túlélés triple negatív betegek esetében 1,15 év, hormonreceptor-pozitív betegek esetében 1,31 év, HER-2-pozitív betegek esetében 3,03 év volt [2].

$\mathrm{Az}$ áttétes emlődaganatok kezelésében széles körben alkalmazott szisztémás kemoterápia és célzott antitestkezelés hatásosságának is a jele, hogy emlődaganatos betegek között a központi idegrendszeri áttétek előfordulása az elmúlt években növekedett. A vér-agy gáton való korlátozott átjutás megakadályozza, hogy ezek a gyógyszerek az agyban is kifejtsék hatásukat, így a zsigeri áttétek szuppressziója ellenére megjelenhetnek az agyi áttétek [1].

A cerebralis metasztázisok kezelésében négynél nem több, tüneteket okozó áttét esetén idegsebészeti beavatkozás jön szóba, amennyiben a daganat extracranialis manifesztációi kontrollálhatók és a beteg általános állapota jó. Sebészileg nehezen hozzáférhető, négynél nem több és $3 \mathrm{~cm}$-nél kisebb áttétek esetén stereotaxiás sugárkezelés jöhet szóba [3]. Multiplex agyi áttétek esetén teljes koponyabesugárzás végezhető, amennyiben a beteg általános állapota ezt lehetővé teszi. A meningealis metasztázisok elsődlegesen választott kezelése az intrathecalis kemoterápia [4].

$\mathrm{Az}$ intracranialis metasztázisok kezelésében a vér-agy gát átjárhatatlansága miatt a szisztémás kemoterápiás kezelésnek nem tulajdonítanak számottevő szerepet. Azonban újabban feltételezik, hogy maga a daganat, illetve a sugárkezelés vér-agy gátat károsító hatása lehetővé teheti a szisztémásan adott kemoterápiás szer eljutását az intracranialisan elhelyezkedő daganathoz is [1]. Kivételt képeznek a csírasejtes daganatok és a lymphomák, amely kórképekben az intracranialisan elhelyezkedő daganat kezelésében a szisztémás kemoterápia standard kezelésnek számít.

\section{Esetbemutatás}

\section{Elsö eset}

A 69 éves nő anamnézisében tonsillectomia, appendectomia, cholecystectomia, obesitas, hypertonia, depreszszió, Algopyrin-érzékenység szerepelt. Kisebb trauma kapcsán jobb oldali, bőrt beszürő emlődaganatot fedezett fel. A szövettan pleiomorph, Grade 3, ER-, PR-, HER-2 tumort igazolt $\left(\mathrm{T}_{4} \mathrm{~N}_{2} \mathrm{M}_{1}\right)$. Mellkas-hasi CT két- oldali axillaris és supraclavicularis nyirokcsomó-metasztázisokat mutatott. A májban kóros eltérés nem ábrázolódott. A tüdőben lymphangitis carcinomatosára utaló eltérések mutatkoztak. A koponya-CT 8 darab, 10-12 mm-es metasztázist ábrázolt, amelyek mindkét hemispheriumot érintették. A cerebralis metasztázisok tünetmentesek voltak.

Palliatív 1. vonalú carboplatin (AUC 5) - docetaxel $\left(75 \mathrm{mg} / \mathrm{m}^{2}\right)$ kemoterápiát kezdtünk, amiből 6 ciklust kapott. A kezelés eredményessége kivételesen jó, de a tolerancia nehéz volt. A kemoterápia mellett a primer tumor szinte teljesen visszahúzódott, a cerebralis metasztázisok komplett radiológiai remisszióba kerültek. Ugyanakkor grade 3 perifériás és vegetatív neuropathiát észleltünk. A mellékhatások miatt az 5-6. ciklust 25\%-os dóziscsökkentéssel adtuk. Az interciklusokat a helyi rehabilitációs osztályon töltötte. Neuropathiás panaszai a kemoterápia befejezését követően javultak. Lehetővé vált, hogy a kezelés befejezése után egyedül hazatérjen.

A felfedezéstől számított 10 hónap múlva kontroll-koponya-CT-n leírt cerebralis relapsus miatt teljes koponyabesugárzást végeztünk $10 \times 3$ Gy dózisban. A kezelés befejezését követően többgócú mastitis carcinomatosa képében jelentkező lokális recidívát észleltünk. 7 ciklus 2. vonalú paclitaxel kemoterápiát, majd további lokális progresszió miatt $10 \times 3$ Gy palliatív mellkasfali sugárkezelést kapott. A 2. vonalú kemoterápiát és a sugárkezeléseket jól tolerálta, relatív önállóságát megtartotta.

Komfort kezelését a helyi rehabilitációs osztályon végezték. A multiplex cerebralis metasztázisokat adó emlődaganat felfedezésétől számítva 20 hónap volt a túlélés.

\section{Második eset}

Az 57 éves nő anamnézisében elhízás, hypertonia és cholecystectomia szerepelt. Mammográfiával igazolt jobb oldali emlőtumor miatt sectorectomia és axillaris blokkdissectio történt, a szövettan $25 \mathrm{~mm}$-es ER+, PR+, HER-2-, $2 \mathrm{~N}+/ 8 \mathrm{~N}$ lobularis carcinomát igazolt $\left(\mathrm{T}_{2} \mathrm{~N}_{1} \mathrm{M}_{0}\right)$. A beteg a felajánlott kemoterápiát nem fogadta el, így 50 Gy posztoperatív irradiációban (maradék emlő + nyirokrégiók) és hormonterápiában (aromatázinhibitor) részesült.

A beteg rendszeresen járt gondozásra. Két év elteltével szédülés, fejfájás, hányinger, dysarthria és bal oldali perifériás facialis paresis lépett fel. A koponya-MRI felvetette meningitis carcinomatosa gyanúját. A diagnózist a liquor citológiai vizsgálata igazolta. 30 Gy egészkoponya-irradiációt kapott, és párhuzamosan intrathecalis methotrexat kemoterápiát kezdtünk. Állapota sokat javult, az eleinte ágyban fekvő beteg önellátóvá vált, a lakásból is kijárt. Liquorsejtszáma egy hónap alatt 65-ről 5-re csökkent. Státuszrögzítő mellkas-has-kismedencei CT multiplex csontmetasztázisokat írt le, zsigeri áttétet nem mutatott. Biszfoszfonát és major analgetikus kezelést indítottunk. 
Négy hónap intrathecalis kemoterápia mellett a jobb infraclavicularis régióban $6 \mathrm{~cm}$-es, tapintható nyirokcsomó-konglomerátum jelent meg. Intrathecalis kezelését felfüggesztettük. Szisztémás kemoterápiát kezdtünk: ifosfamid $\left(1000 \mathrm{mg} / \mathrm{m}^{2}, \mathrm{l}-3\right.$. nap $)$ - etoposid (100 mg/ $\mathrm{m}^{2}, 1-3$. nap), protokoll szerint. Az első kúra végén komplett klinikai remissziót észleltünk, és neurológiai tünetei sem tértek vissza. Összesen 6 ciklus szisztémás kemoterápia után állapota házi munkavégzésre végig alkalmas volt, a kezeléstől komolyabb mellékhatást nem észleltünk. Tumormarkerértéke a harmadára csökkent. Liquorsejtszáma a kemoterápia alatt stabilan 5 alatt maradt.

Deréktáji fájdalom, kontroll-CT által leírt ossealis progresszió miatt palliatív lumbalis gerinc irradiációt kapott $10 \times 3$ Gy dózisban. A radioterápia végén csontfájdalmai csökkentek, azonban neurológiai tünetei ismét rosszabbodtak. Terápiás konzekvencia híján további vizsgálatokat nem javasoltunk. Komfort terápiáját krónikus részlegünkön biztosítottuk. A meningitis carcinomatosa diagnózisa után 13 hónap volt a túlélés.

\section{Megbeszélés}

Szolid daganatok cerebralis metasztázisainak kezelésében néhány szisztémásan adott kemoterápiás szer hatásosságáról rendelkezésünkre állnak eseti beszámolók (1. táblázat) $[1,5]$. Randomizált, kontrollált vizsgálatok ebben a betegcsoportban nem történtek [3], és a speciális helyzetre való tekintettel nem is számíthatunk rá, hogy a közeljövőben ilyen vizsgálatokat végezzenek. Egy prospektív vizsgálatban a cisplatin-etoposid kombináció agyi áttétes emlődaganatos betegek 38\%-ánál, nem kissejtes tüdődaganatos betegek 30\%-ánál biztosított parciális vagy komplett remissziót [5]. Randomizált vizsgálatok hiányában az esetbemutatások is felértékelődnek.

1. táblázat |Emlődaganat agyi áttétei kezelésében hatásosnak észlelt sziszté más kemoterápiás szerek a hatásmechanizmus alapján csoportosítva

\begin{tabular}{l}
\hline Alkilálószerek \\
Bendamustin \\
Ciklofoszfamid \\
Temozolomid \\
Pirimidinszintézis-gátlók \\
Methotrexat \\
5-fluorouracil \\
Capecitabin \\
Topoizomerázgátlók \\
Etoposid \\
Mikrotubulus-gátlók \\
Vincristin \\
Platinaszármazékok \\
Cisplatin
\end{tabular}
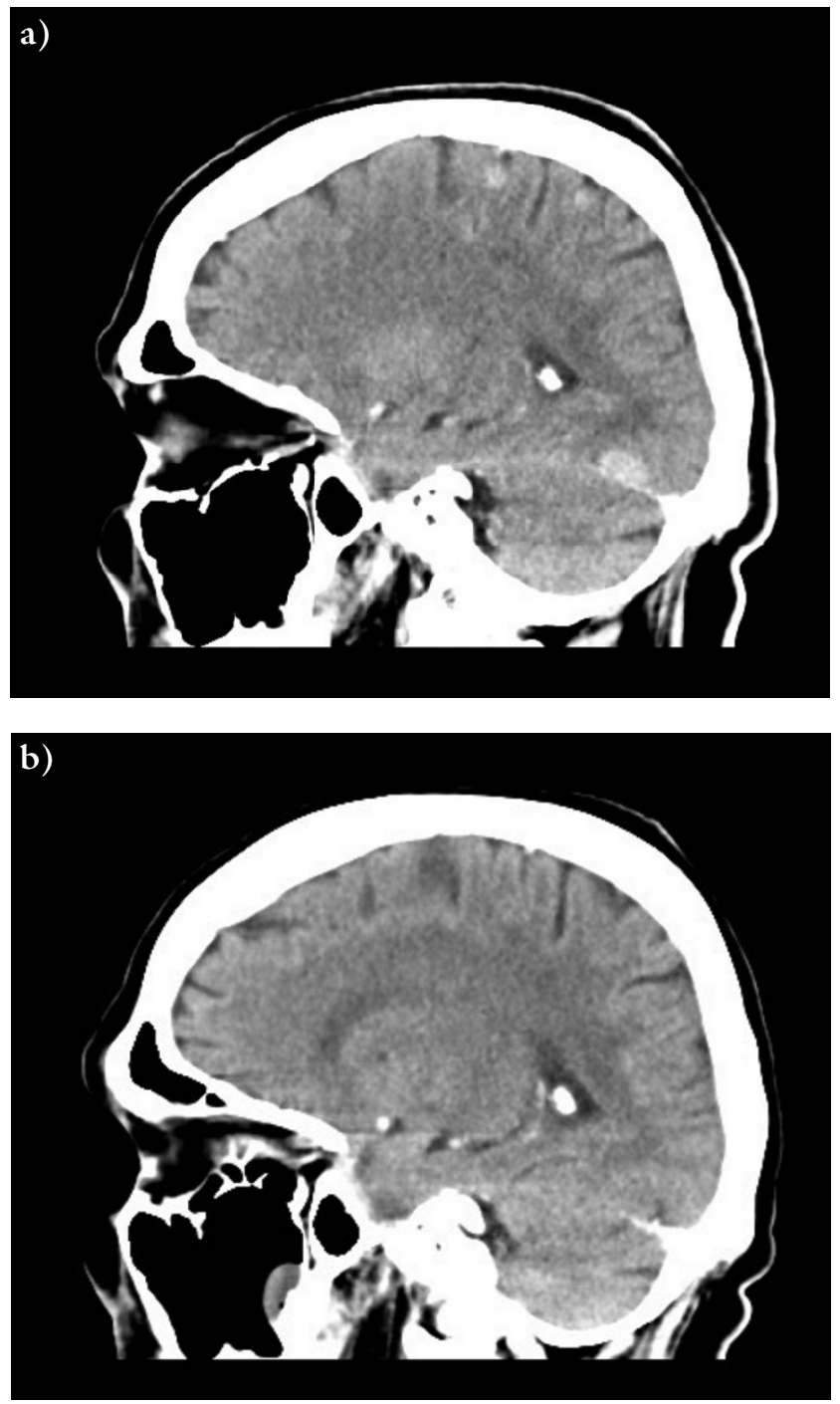

\begin{tabular}{l|l} 
1. ábra & Három agyi metasztázis (a) és azok radiológiai remissziója (b) 6
\end{tabular} ciklus carboplatin-docetaxel kezelés mellett (bal oldali parasagittalis metszet)

Első esetünkben az agyi áttétek diagnózisa melléklelet volt. Emlődaganatos betegeknél neurológiai tünetek hiányában a primer stagingnek nem feltétlenül része a koponya-CT- vagy MR-vizsgálat [3]. Esetünkben a klinikum alapján gyorsan progrediáló triple negatív tumorra való tekintettel kértük a vizsgálatot. Az agyi metasztázisok kimutatásában az MRI érzékenyebb, mint a CT-vizsgálat. Tekintettel arra, hogy a primer staging CT multiplex cerebralis metasztázisokat mutatott, MRI végzésének akkor nem volt terápiás konzekvenciája. A kontroll-koponya-CT-vizsgálattal észlelt komplett radiológiai remissziót (1. ábra) azonban MR-vizsgálattal is megerősítettük.

A multiplex agyi metasztázisok elsőnek választandó kezelése a mai magyar onkológiai gyakorlatban a teljes koponyabesugárzás (WGRT). Tekintettel arra, hogy az emlődaganat lokálisan destruktív volt, a pulmonalis lymphangitis carcinomatosa terhelési nehézlégzést okozott, az agyi áttétek viszont tünetmentesek voltak, a 
szisztémás kemoterápia alkalmazását részesítettük előnyben a sugárkezeléshez képest. A docetaxel-carboplatin kombinációt a triple negatív emlődaganatokban leírt jó hatásossága miatt választottuk [6]. Az agyi áttétek eltünése nem várt kedvező lelet volt, és lehetővé tette a teljes koponyabesugárzás 10 hónappal történő halasztását. Tudomásunk szerint ez az első olyan közölt eset, amikor az emlődaganat okozta agyi áttétek docetaxel-carboplatin kombináció mellett komplett radiológiai remissziót mutattak.

A kemoterápia toleranciája nem volt könnyú. Általános gyengeség és járási nehezítettség jelentkezett, közvetlenül az ágyból történő felkelést követően ismételten előforduló elesésekkel. A panaszokat perifériás és vegetatív neuropathiával és szekunder orthostaticus hypotensióval magyaráztuk. Az interciklusokat a beteg az állandó felügyelet biztosíthatósága kedvéért rehabilitációs osztályon töltötte. A beteg panaszai a kemoterápia befejezését követően jelentősen javultak, és lehetővé vált, hogy egyedül otthonába hazatérjen. Nem tudjuk, hogy az agyi metasztázisokon észlelt váratlan hatásosság és a viszonylag jelentős neurotoxicitás között van-e összefüggés.

A második esetben a szisztémás kemoterápia egyaránt biztosította az intrathecalis kezeléssel elért neurológiai tünetmentességet és a zsigeri metasztázisok kontrollját. A kemoterápianaiv betegnél olyan szisztémás kemoterápiás kombinációt kellett választanunk, amely a vér-agy gáton a lehető legnagyobb valószínűséggel jut át. Az irodalomban a legtöbb, vér-agy gáton történő bejutást alátámasztó adat az alkilálószerekkel és az etoposiddal kapcsolatban gyúlt össze $[1,5]$. A hazai kemoterápiás gyưjteményben nem szereplő ifosfamid-etoposid kombinációt a fellelhetô irodalom és korábbi személyes tapasztalatok alapján választottuk.

A leptomeningealis carcinomatosis diagnosztikus buktatóit és az intrathecalis kemoterápiát illetően utalunk korábbi közleményünkre [4]. Itt csupán annyit kívánunk aláhúzni, hogy a diagnóziskor megőrzött általános állapot, a daganat hormonpozitivitása, illetve a megelőző szisztémás kemoterápia hiánya az intrathecalis kemoterápia jó prediktív markerei.

Felvetődik a kérdés, hogy az adjuváns kemoterápia visszautasítása mennyiben korlátozhatta a betegség kimenetelét. A hagyományos felfogás szerint - tekintettel arra, hogy a posztoperatív sémákban alkalmazott antracyclin, taxán és alkilálószerek egyike sem jut be biztonsággal a vér-agy gáton - a meningitis carcinomatosa, amely a betegség prognózisát döntően befolyásolta, adjuváns kemoterápia mellett is kialakult volna. A bemutatott előző eset ismeretében azonban nem zárható ki, hogy a kezelés még a meningealis propagáció ellen is nyújthatott volna védelmet.

A meningitis carcinomatosa adjuváns aromatázgátló hormonkezelés mellett alakult ki. A hormonreceptor-pozitív tumorok esetén a triple negatív és HER-2-pozitív tumorokhoz képest az intracranialis áttétek később jelennek meg és lassabban fejlődnek. A tamoxifen átjut a vér-agy gáton és növeli az agyi áttétes betegek teljes túlélését $[1,7]$. Az aromatázgátlók és a fulvestrant az intracranialis áttétek kezelésében nem hatásosak [1].

Mindkét bemutatott eset HER-2-negatív daganatról szólt. A HER-2-pozitív emlődaganatos betegeknél a zsigeri metasztázisok kezelésében alkalmazott trastuzumab, pertuzumab és TDM-l is képes az agyi áttétek progresszióját lassítani, illetve a teljes túlélést növelni [8-10], bár ebben az indikációban alkalmazásukra egyértelmü ajánlás még nem született. Meningitis carcinomatosa esetén intrathecalis trastuzumabkezelés mellett elért komplett klinikai remisszióról is szól esettanulmány [11].

\section{Következtetés}

Szisztémás kemoterápia hatásos lehet emlődaganatok intracranialis áttéteinek palliatív kezelésében.

Anyagi támogatás: A közlemény megírása anyagi támogatásban nem részesült.

Szerzôi munkamegosztás: S. I., K. T.: A betegek kezelése, a közlemény összeállítása. S. Z., P. T.: Véleményezés, javítás. A cikk végleges változatát valamennyi szerző elolvasta és jóváhagyta.

Érdekeltségek: A szerzőknek a közlemény megjelentetésével kapcsolatban nincsenek érdekeltségeik.

\section{Irodalom}

[1] Lin, N. U., Bellon, J. R., Winer, E. P.: CNS metastases in breast cancer. J. Clin. Oncol., 2004, 22(17), 3608-3617.

[2] McKee, M. J., Keith, K., Deal, A. M., et al.: A multidisciplinary breast cancer brain metastases clinic: The University of North Carolina experience. Oncologist, 2016, 21(1), 16-20.

[3] Ramakrishna, N., Temin, S., Chandarlapaty, S., et al.: Recommendations on disease management for patients with advanced human epidermal growth factor receptor 2-positive breast cancer and brain metastases: American Society of Clinical Oncology clinical practice guideline. J. Clin. Oncol., 2014, 32(19), 21002108.

[4] Kullmann, T., Gauthier, H., le Maignan, C., et al.: Intrathecal methotrexate chemotherapy for leptomeningeal carcinomatosis. [Meningitis carcinomatosa kezelése intrathecalis methotrexatkemoterápiával.] Orv. Hetil., 2012, 153(35), 1385-1388. [Hungarian]

[5] Franciosi, V., Cocconi, G., Michiara, M., et al.: Front-line chemotherapy with cisplatin and etoposide for patients with brain metastases from breast carcinoma, nonsmall cell lung carcinoma, or malignant melanoma: a prospective study. Cancer, 1999, 85(7), 1599-1605.

[6] Sharma, P., López-Tarruella, S., Garcia-Saenz, J. A., et al.: Efficacy of neoadjuvant carboplatin plus docetaxel in triple negative breast cancer: Combined analysis of two cohorts. Clin. Cancer Res., 2016 Jun 14. pii: clincanres.0162.2016. [Epub ahead of print]

[7] Bai, B., Yuan, Z. Y., Liu, D. G., et al.: Clinical features and survival analysis of different subtypes of patients with breast cancer brain metastases. Chin. J. Cancer, 2010, 29(4), 413-419. 
[8] Brufsky, A. M., Mayer, M., Rugo, H. S., et al.: Central nervous system metastases in patients with HER2-positive metastatic breast cancer: incidence, treatment, and survival in patients from registHER. Clin. Cancer Res., 2011, 17(14), 4834-4843.

[9] Swain, S. M., Baselga, J., Miles, D., et al.: Incidence of central nervous system metastases in patients with HER2-positive metastatic breast cancer treated with pertuzumab, trastuzumab, and docetaxel: results from the randomized phase III study CLEOPATRA. Ann. Oncol. 2014, 25(6), 1116-1121.

[10] Krop, I. E., Lin, N. U., Blackwell, K., et al.: Trastuzumab emtansine (T-DMl) versus lapatinib plus capecitabine in patients with HER2-positive metastatic breast cancer and central nervous sys- tem metastases: a retrospective, exploratory analysis in EMILIA. Ann. Oncol., 2015, 26(1), 113-119.

[11] Oliveira, M., Braga, S., Passos-Coelho, J. L., et al.: Complete response in HER2 + leptomeningeal carcinomatosis from breast cancer with intrathecal trastuzumab. Breast Cancer Res. Treat., $2011,127(3), 841-844$

(Kullmann Tamás dr., Gyơr, Vasvári Pál u. 2-4, 9024 e-mail: kullmanndoki@hotmail.com)

\section{A Kuthy Elek Egészségügyi Intézmény ÁLLÁSPÁLYÁZATA orvos munkakörben}

A tiszafüredi Kuthy Elek Egészségügyi Intézmény 2016-ban az alábbi szakellátásokban megüresedett állások pályázatára kínál lehetőséget.

Az alábbi munkaköröket közremüködői szerződés vagy közalkalmazotti státusz keretében töltheti be a pályázó.

\begin{tabular}{|c|c|c|c|}
\hline $\begin{array}{l}\text { A pályázatot meghirdeto” } \\
\text { szerv neve, címe }\end{array}$ & Munkakör megnevezése & Pályázati feltételek & Juttatások \\
\hline $\begin{array}{l}\text { Kuthy Elek Eü. Intézmény } \\
5350 \text { Tiszafüred } \\
\text { Nefelejcs út } 4 .\end{array}$ & $\begin{array}{l}\text { - Gyermekorvos } \\
\text { - Pszichológus } \\
\text { - Nőgyógyász } \\
\text { - Bőrgyógyász } \\
\text { - Szemész szakorvos }\end{array}$ & $\begin{array}{l}\text { - Szakirányú szakképesítés } \\
\text { - Részletes szakmai } \\
\text { önéletrajz } \\
\text { - MOK-tagsági igazolvány } \\
\text { - Múködési nyilvántartásba } \\
\text { vétel igazolása } \\
\text { - } 3 \text { hónapnál nem régebbi } \\
\text { erkölcsi bizonyítvány }\end{array}$ & $\begin{array}{l}\text { Juttatások megegyezés } \\
\text { szerint. }\end{array}$ \\
\hline
\end{tabular}

Pályázati határidő: az állások betöltésével véges.

A pályázattal kapcsolatban további információt Habuczki Árpád, az Intézmény gazdasági dolgozója ad. Tel: 06/59/351-244; 06/30/493-7843

Kérjük, hogy a pályázat benyújtásával egy időben személyesen keresse fel az Intézmény orvos igazgatóját, Dr. Hegyi György Pétert. Tel: 06/70/940-8738

A pályázatot az alábbi címre kérjük benyújtani:

\section{Dr. Hegyi György Péter Orvos-igazgató} 5350 Tiszafüred, Nefelejcs út 4.,

illetve a kuthyelek@gmail.com e-mail címre.

Tiszafüred, 2016. október 4. 